\title{
New Opportunities in International Horticultural Consulting
}

\author{
Roland Ebel ${ }^{1,2}$ \\ Agricultural Sciences, Autonomous University of the State of Mexico, Ignacio Allende 225, 50000 Toluca de Lerdo, \\ Mexico
}

Political changes in multiple countries and the global withdrawal of trade barriers are diversifying the horticultural landscape, creating new players in the horticultural world map as well as strengthening older ones. Apart from global politics and economics, many developing countries question whether they should continue producing crops they have exported for centuries and are now diversifying their portfolio. As a result, for example, horticultural exports from Latin America have more than tripled since the 1990s, whereas those from Africa and Asia have even quadrupled (Van den Broeck and Maertens, 2016).

These developments offer prosperity for horticulturists in the developing world, although they also challenge traditional Western producers. Yet, growing exports do not necessarily mean increasing food security: in most emerging economies, small-scaled producers are widely excluded from the rising wealth through horticulture; social conditions of farm workers are questionable in many countries; and the economic growth is often based on an overexploitation of natural resources.

Asia has undoubtedly been the hotspot of both recent growth and its social consequences; Asia is also the place where most new players have emerged. One example is Myanmar, a country that has the potential to become a relevant horticultural producer and exporter. However, current yields of most fruits and vegetables are well below world averages. This is attributed to a poor knowledge transfer at the national level. Because of a long political isolation, higher education in Myanmar has fallen far behind modern standards. Now, to provide meaningful support for local producers, academics need (informational and material) inputs in almost all horticultural sectors. To make things worse, the country is remarkably challenged by changing climatic conditions, particularly by increasing precipitation. This makes Myanmar a consultancy destination consideration for innovative researchers and those who would like to become real pioneers in horticultural advisory.

A further Asian newcomer on the global market is Iran. The country ranks first in fruit and second in vegetable production in the Middle East, but has lacked access to many Western markets for decades. Iran, center of origin of many of the world's most eaten fruits (apple, fig, and pomegranate), is benefited through its proximity to the Persian Gulf and to Europe as well as through its climate- and agrobiodiversity. Although Iran counts with experienced producers and recognized universities, its horticultural industry struggles with technical limitations to exploit the full potential of the country. It is particularly essential that postharvest handling, storage, and transportation are improved. Eventually, the success of Iranian horticulture will depend on political issues. However, experienced consultants should be able to aid with the postharvest management.

Countries such as Kenya, Ghana, Ethiopia, Malaysia, the Philippines, Colombia, or Peru are not new on the international agricultural market. Yet, they have achieved considerable growth (Van den Broeck and Maertens, 2016) thanks to a diversification of their exportation crops (especially of horticultural plants), and simultaneously, by lowering the priority of their classical export goods (e.g., coffee, cocoa, sugar, banana, and citrus fruits). The Dominican Republic is one of many nations that are making an effort to follow this path. There, peppers are becoming a crop of increasing importance. Nevertheless, local producers need to learn how to deal with heat stress in indoor production - a fascinating mission for motivated consultants.

In conclusion, international consultancy opportunities are now available in many areas and many countries. To succeed, expertise is as important as cultural openness and flexibility: International consultancy has become a hybrid of information and knowledge transfer, organization facilitation, conflict, and communication management.

The 2016 Workshop of the International Horticultural Consultants Working Group of the ASHS gave a review of some of the most exciting developments in emerging horticultural markets and, thus, highlighted new opportunities in horticultural consulting. The following series of articles deepens the information presented at the workshop and enriches it with the principal skills and traits a consultant needs to succeed abroad. We hope to motivate young (and not so young) horticulturists to go internationala way to work, to learn, to teach, and most notably an unforgettable experience.

\section{Literature Cited}

Van den Broeck, G. and M. Maertens. 2016. Horticultural exports and food security in developing countries. Glob. Food Secur. 10:11-20.

\footnotetext{
Received for publication 10 July 2017. Accepted for publication 30 July 2017 .

This paper is an introduction to the Workshop titled "Seize Your Future Internationally: New Opportunities in Horticultural Consulting" that was presented during the 2016 ASHS Annual Conference, Atlanta, GA.

${ }^{1}$ Workshop Coordinator.

${ }^{2}$ Corresponding author. E-mail: roland.ebel@gmx. com.
} 